\title{
Inhibition by minodronate of basic fibroblast growth factor-stimulated vascular endothelial growth factor synthesis in osteoblast-like cells
}

\author{
HARUHIKO TOKUDA ${ }^{1,3}$, SEIJI ADACHI ${ }^{3}$, RIE MATSUSHIMA-NISHIWAKI ${ }^{3}$, YOSHITERU HANAI ${ }^{1,3}$, \\ SHINJI TAKAI ${ }^{3}$, ATSUSHI HARADA ${ }^{2}$ and OSAMU KOZAWA ${ }^{3}$ \\ Departments of ${ }^{1}$ Clinical Laboratory, and ${ }^{2}$ Functional Restoration, National Hospital for Geriatric Medicine, \\ National Center for Geriatrics and Gerontology, Obu, Aichi 474-8511; ${ }^{3}$ Department of Pharmacology, \\ Gifu University Graduate School of Medicine, Gifu 501-1194, Japan
}

Received July 17, 2009; Accepted August 26, 2009

DOI: $10.3892 / \mathrm{mmr} 00000235$

\begin{abstract}
In our previous study, we showed that basic fibroblast growth factor (bFGF) stimulates the synthesis of vascular endothelial growth factor (VEGF) via the activation of p44/p42 mitogen-activated protein (MAP) kinase and stress-activated protein kinase/c-Jun $N$-terminal kinase (SAPK/JNK) in osteoblast-like MC3T3-E1 cells. In the present study, we investigated the effect of minodronate, a newly developed bisphosphonate, on bFGF-induced VEGF synthesis in MC3T3-E1 cells. Minodronate significantly reduced the synthesis of VEGF induced by bFGF in a dose-dependent manner in a range between 3 and $100 \mu \mathrm{M}$. The bFGF-stimulated phosphorylation of p44/p42 MAP kinase and SAPK/JNK was reduced by minodronate. These results strongly suggest that minodronate suppresses bFGF-stimulated VEGF synthesis via the inhibition of p44/p42 MAP kinase and SAPK/JNK in osteoblasts.
\end{abstract}

\section{Introduction}

Osteoblasts and osteoclasts are main functional cells that regulate bone metabolism; the former are responsible for bone formation and the latter for bone resorption (1). Bone remodeling results from a finely coordinated process involving bone resorption by activated osteoclasts coupled with subsequent deposition of new matrix by osteoblasts. Several bone resorptive agents, such as parathyroid hormone and $1.25-(\mathrm{OH})_{2}$ vitamin $\mathrm{D}_{3}$, up-regulate RANKL (receptor activator of nuclear factor $\kappa \mathrm{B}$ ligand) expression by binding specific receptors on osteoblasts. This suggests that osteoblasts also play crucial role in the regulation of bone

Correspondence to: Dr Haruhiko Tokuda, Department of Clinical Laboratory, National Hospital for Geriatric Medicine, National Center for Geriatrics and Gerontology, Obu, Aichi 474-8511, Japan E-mail: tokuda@ncgg.go.jp

Key words: bisphosphonate, basic fibroblast growth factor, vascular endothelial growth factor, osteoblast resorption (2). During this process, capillary endothelial cells provide the microvasculature, and osteoblasts and osteoprogenitor cells, which locally proliferate and differentiate into osteoblasts, migrate into the resorption lacuna. Therefore, it is recognized that osteoblasts, osteoclasts and capillary endothelial cells cooperatively regulate bone metabolism in a closely coordinated fashion via humoral factors as well as by direct cell-to-cell contact (3).

Bisphosphonate, a stable analogue of pyrophosphate, is generally known as an inhibitor of bone resorption (4). Bisphosphonate is widely used as a potent agent for the treatment of various metabolic bone diseases associated with increased osteoclastic bone resorption, such as Paget's disease, tumoral bone disease and osteoporosis (4). It is recognized that the inhibition of osteoclast recruitment, osteoclastic adhesion to bone surface and osteoclast activity are the main mechanisms of the anti-bone resorptive actions of bisphosphonate (4). In addition to osteoclasts, it has been reported that the inhibitory action on osteoclasts of bisphosphonates is partly mediated through its actions on osteoblasts $(5,6)$. In the osteoblastic cell line CRP 10/30, ibandronate as well as alendronate induced the synthesis of an inhibitor of osteoclastic bone resorption (7). In a previous study, we reported that tiludronate inhibits interleukin (IL)-6 synthesis in osteoblast-like MC3T3-E1 cells (8). Ethidronate, alendronate, pamidronate and olpadronate prevented the apoptosis of murine primary cultured osteoblasts through the activation of $\mathrm{p} 44 / \mathrm{p} 42$ mitogen-activated protein (MAP) kinase (9). In cultured human fetal osteoblasts, pamidronate and zoledronate enhanced differentiation and bone formation activities (10). It has also been reported that pamidronate and zoledronate increase the expression of mRNA for osteoprotegerin in primary human osteoblasts (11). In UMR-106-01 osteosarcoma cells, pamidronate and clodronate decreased RANKL (12). In addition, in human osteoblastlike cells $(13,14)$, zoledronate up-regulated osteocalcin and bone morphogenetic protein-2 (BMP-2) gene expression, and decreased membrane RANKL expression by up-regulating tumor necrosis factor- $\alpha$ converting enzyme. These studies led us to speculate that the effects of bisphosphonates on bone metabolism are exerted not only through osteoclasts but also by 
osteoblasts. However, the detailed mechanisms of bisphosphonate action in osteoblasts have yet to be fully clarified.

Vascular endothelial growth factor (VEGF) is a potent angiogenic factor that induces angiogenesis, endothelial cell proliferation and capillary permeability (15). Regarding bone metabolism, the inactivation of VEGF reportedly results in the complete suppression of vascular invasion followed by impaired trabecular bone formation and the expansion of the hypertrophic chondrocyte zone in mouse tibial epiphyseal growth plates (16). It has been reported that osteoblasts produce and secrete VEGF in response to various physiological agonists $(15,17)$. In our previous studies, we showed that bFGF positively regulates VEGF synthesis and secretion through p44/p42 MAP kinase and stress-activated protein kinase/c-Jun $\mathrm{N}$-terminal kinase (SAPK/JNK) among the MAP kinase superfamily in osteoblast-like MC3T3-E1 cells $(18,19)$. Furthermore, we demonstrated that incadronate enhances prostaglandin $F_{2 \alpha}$ $\left(\mathrm{PGF}_{2 \alpha}\right)$-induced VEGF synthesis through the activation of p44/p42 MAP kinase in osteoblast-like MC3T3-E1 cells, while alendronate or etidronate have little such effect (20).

In the present study, we investigated the effect of minodronate, a newly developed nitrogen-containing bisphosphonate that is structurally different and has different side chain structure from incadronate, alendronate or ethidronate, on bFGF-stimulated VEGF synthesis in MC3T3-E1 cells, as well as the mechanisms behind its action. Minodronate was shown to suppress bFGF-stimulated VEGF synthesis in these cells. Its suppressive effect was apparently exerted through the inhibition of p44/p42 MAP kinase and SAPK/JNK.

\section{Materials and methods}

Materials. Minodronate was kindly provided by Astellas Pharma Ltd. (Tokyo, Japan). bFGF was purchased from Sigma Chemical Co. (St. Louis, MO, USA). Phospho-specific p44/ p42 MAP kinase antibodies, p44/p42 MAP kinase antibodies, phospho-specific p38 MAP kinase antibodies, p38 MAP kinase antibodies, phospho-specific SAPK/JNK antibodies and SAPK/JNK antibodies were purchased from Cell Signaling Technology, Inc. (Beverly, MA, USA). The ECL Western blot analysis detection system was purchased from Amersham Japan (Tokyo, Japan). A mouse VEGF ELISA kit was purchased from R\&D Systems, Inc. (Minneapolis, MN, USA). Other materials and chemicals were obtained from commercial sources.

Cell culture. Cloned osteoblast-like MC3T3-E1 cells derived from newborn mouse calvaria (21) were maintained as previously described (22). The cells were cultured in $\alpha$-minimum essential medium ( $\alpha$-MEM) containing $10 \%$ fetal calf serum (FCS) at $37^{\circ} \mathrm{C}$ in a humidified atmosphere of $5 \%$ $\mathrm{CO}_{2} / 95 \%$ air. The cells were seeded into $35-\mathrm{mm}\left(5 \times 10^{4}\right)$ or 90-mm $\left(2 \times 10^{5}\right)$ diameter dishes in $\alpha$-MEM containing $10 \%$ FCS. After 5 days, the medium was exchanged for $\alpha$-MEM containing $0.3 \%$ FCS. The cells were used for experiments after $48 \mathrm{~h}$.

Assay for VEGF. Cells were pre-treated with various doses of minodronate or vehicle for $8 \mathrm{~h}$ and then stimulated by bFGF in $1 \mathrm{ml}$ of $\alpha$-MEM containing $0.3 \%$ FCS for the indicated periods. The conditioned medium was collected and VEGF in the medium was measured by the VEGF ELISA kit.

Analysis of p44/p42 MAP kinase, SAPK/JNK or p38 MAP kinase. The cultured cells were pre-treated with various doses of minodronate or vehicle for $8 \mathrm{~h}$ and then stimulated by bFGF in $4 \mathrm{ml}$ of $\alpha$-MEM containing $0.3 \%$ FCS for the indicated periods. The cells were washed twice with phosphatebuffered saline and then lysed, homogenized and sonicated in a lysis buffer containing $62.5 \mathrm{mM}$ Tris/ $\mathrm{HCl}, \mathrm{pH} 6.8,2 \%$ sodium dodecyl sulfate (SDS), $50 \mathrm{mM}$ dithiothreitol and $10 \%$ glycerol. SDS-PAGE was performed as described by Laemmli (23) in $10 \%$ polyacrylamide gel. Western blot analysis was performed as described previously (24) using phosphospecific p44/p42 MAP kinase antibodies, p44/p42 MAP kinase antibodies, phospho-specific SAPK/JNK antibodies, SAPK/JNK antibodies, phospho-specific p38 MAP kinase antibodies or p38 MAP kinase antibodies, with peroxidaselabeled antibodies raised in goat against rabbit IgG used as second antibodies. Peroxidase activity on the PVDF sheet was visualized on X-ray film by means of the ECL Western blotting detection system.

Determination. The absorbance of ELISA samples was measured at $450 \mathrm{~nm}$ with a microplate spectrophotometer (Bio-Rad Laboratories, Hercules, CA, USA). Densitometric analysis was performed using scanner and image analysis software (ImageJ ver. $1.33 \mathrm{u}$ ).

Statistical analysis. Data were analyzed by ANOVA followed by the Bonferroni method for multiple comparisons between pairs. A value of $\mathrm{p}<0.05$ was considered significant. All data are presented as the mean \pm SD of triplicate determinations. Each experiment was repeated three times with similar results.

\section{Results}

Effect of minodronate on bFGF-induced VEGF synthesis in MC3T3-E1 cells. Recently, we reported that bFGF induces the synthesis of VEGF in osteoblast-like MC3T3-E1 cells $(18,19)$. Consequently, we investigated the effect of minodronate on bFGF-induced VEGF synthesis in these cells. Although minodronate alone had little effect on VEGF levels, it significantly suppressed bFGF-induced VEGF synthesis in MC3T3-E1 cells (Fig. 1). The inhibitory effect of minodronate was dose-dependent between 3 and $100 \mu \mathrm{M}$. Minodronate at a dose of $30 \mu \mathrm{M}$ caused an $\sim 80 \%$ reduction in the bFGF effect.

Effect of minodronate on the phosphorylation of $44 / p 42$ MAP kinase induced by bFGF in MC3T3-E1 cells. We previously found that bFGF-induced VEGF synthesis is mediated via p44/p42 MAP kinase in osteoblast-like MC3T3-E1 cells (18). Thus, we next examined the effect of minodronate on the phosphorylation of p44/p42 MAP kinase induced by bFGF. Minodronate, which by itself did not affect the phosphorylation of p44/p42 MAP kinase, significantly suppressed bFGFinduced p44/p42 MAP kinase phosphorylation (Fig. 2). According to densitometric analysis, $30 \mu \mathrm{M}$ of minodronate caused an $\sim 70 \%$ reduction in the bFGF effect. 


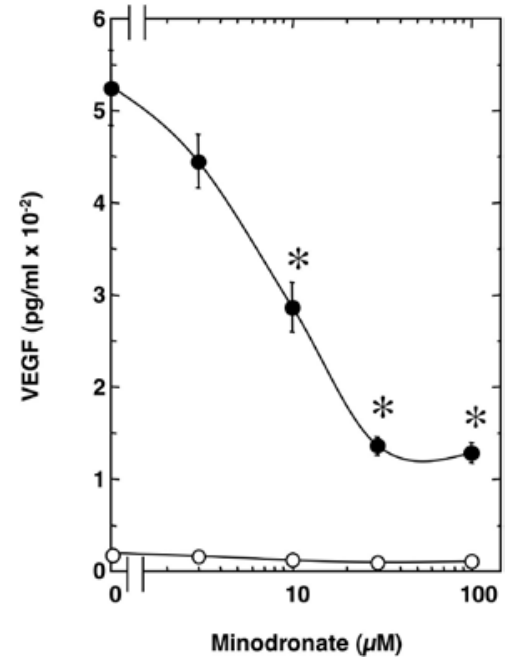

Figure 1. Effect of minodronate on bFGF-induced VEGF synthesis in MC3T3-E1 cells. The cultured cells were pre-treated with various doses of minodronate for $8 \mathrm{~h}$ and then stimulated by $70 \mathrm{ng} / \mathrm{ml}$ bFGF (closed bars) or vehicle (open bars) for $24 \mathrm{~h}$. Cell viability after the treatments was $>90 \%$ of the control cells. Each value represents the mean \pm SD of triplicate determinations. Similar results were obtained with two additional and different cell preparations. ${ }^{*} \mathrm{P}<0.05$ compared to the value of bFGF alone.

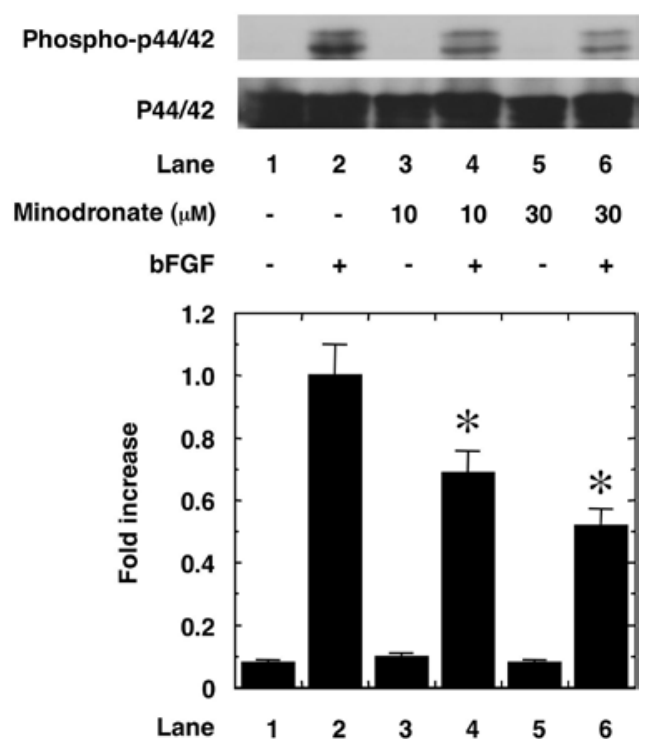

Figure 2. Effect of minodronate on the bFGF-induced phosphorylation of p44/ p42 MAP kinase in MC3T3-E1 cells. The cultured cells were pre-treated with various doses of minodronate for $8 \mathrm{~h}$ and then stimulated by $70 \mathrm{ng} / \mathrm{ml} \mathrm{bFGF}$ or vehicle for $30 \mathrm{~min}$. Extracts of cells were subjected to SDS-PAGE with subsequent Western blot analysis using antibodies against phospho-specific $\mathrm{p} 44 / \mathrm{p} 42$ MAP kinase or p44/p42 MAP kinase. The histogram shows quantitative representations of p44/p42 MAP kinase phosphorylation obtained from laser densitometric analysis. Each value represents the mean $\pm \mathrm{SD}$ of triplicate determinations. Similar results were obtained with two additional and different cell preparations. "P $<0.05$ compared to the value of bFGF alone.

Effect of minodronate on the phosphorylation of SAPK/ $J N K$ induced by bFGF in MC3T3-E1 cells. Previously, we reported that SAPK/JNK in addition to p44/p42 MAP kinase positively participate in bFGF-stimulated VEGF synthesis in osteoblast-like MC3T3-E1 cells (19). We examined the effect of minodronate on bFGF-stimulated SAPK/JNK phosphorylation. Minodronate alone failed to affect SAPK/JNK phosphoryla-

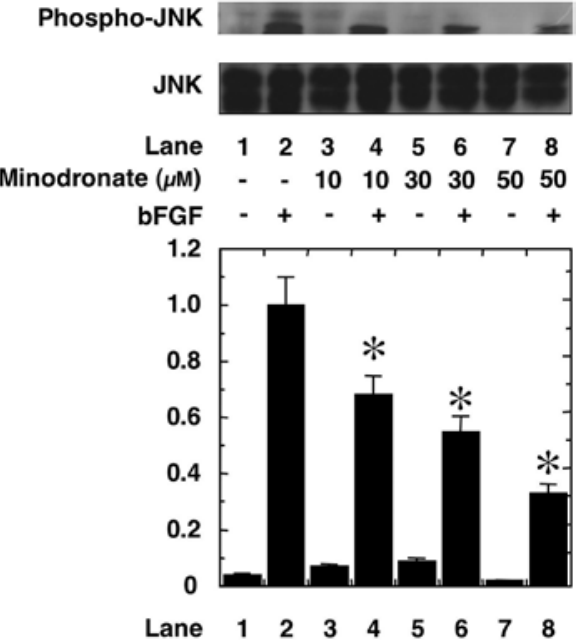

Figure 3. Effect of minodronate on the phosphorylation of SAPK/JNK induced by bFGF in MC3T3-E1 cells. The cultured cells were pre-treated with various doses of minodronate for $8 \mathrm{~h}$ and then stimulated by $70 \mathrm{ng} / \mathrm{ml} \mathrm{bFGF}$ or vehicle for $30 \mathrm{~min}$. Extracts of cells were subjected to SDS-PAGE with subsequent Western blot analysis using antibodies against phospho-specific SAPK/JNK or SAPK/JNK. The histogram shows quantitative representations of SAPK/ JNK phosphorylation obtained from laser densitometric analysis. Each value represents the mean \pm SD of triplicate determinations. Similar results were obtained with two additional and different cell preparations. ${ }^{*} \mathrm{P}<0.05$ compared to the value of bFGF alone.

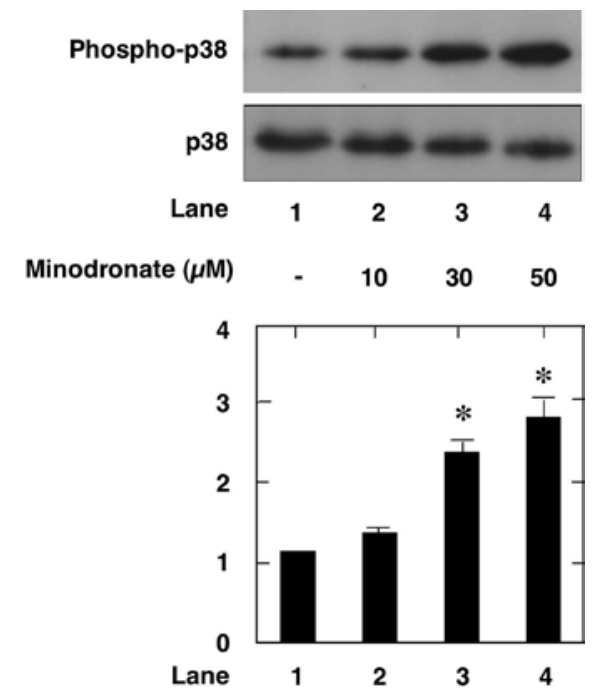

Figure 4. Effect of minodronate on the phosphorylation of p38 MAP kinase in MC3T3-E1 cells. The cultured cells were incubated with various doses of minodronate for $8 \mathrm{~h}$. Extracts of cells were subjected to SDS-PAGE with subsequent Western blot analysis using antibodies against phospho-specific p38 MAP kinase or p38 MAP kinase. The histogram shows quantitative representations of p38 MAP kinase phosphorylation obtained from laser densitometric analysis. Each value represents the mean \pm SD of triplicate determinations. Similar results were obtained with two additional and different cell preparations. ${ }^{*} \mathrm{P}<0.05$ compared to the value of the control.

tion, but markedly reduced the bFGF-induced phosphorylation of SAPK/JNK (Fig. 3). According to densitometric analysis, minodronate $(50 \mu \mathrm{M})$ caused an $\sim 80 \%$ reduction in the bFGF effect.

Among the MAP kinase superfamily, p38 MAP kinase as well as p44/p42 MAP kinase and SAPK/JNK are known to be central elements used by mammalian cells to transduce diverse 
messages (25). Minodronate alone significantly induced the phosphorylation of p38 MAP kinase in a dose-dependent manner in MC3T3-E1 cells (Fig. 4).

\section{Discussion}

In the present study, we showed that minodronate inhibited bFGF-induced VEGF synthesis in osteoblast-like MC3T3-E1 cells. In contrast to the inhibitory effect of minodronate presented here, we recently reported that incadronate enhances VEGF synthesis induced by $\mathrm{PGF}_{2 \alpha}$ in these cells, though VEGF synthesis was not affected by alendronate or etidronate (20). Therefore, our findings suggest that the suppressive effect of minodronate on bFGF-stimulated VEGF synthesis was a specific effect of this agent, and is not a common effect of bisphosphonates. Based on these findings, it is probable that the specific effects of each agent are involved in clinical applications. This supports our results regarding the agent-specific effect of bisphosphonate.

We previously reported that bFGF activates p44/p42 MAP kinase and SAPK/JNK in osteoblast-like MC3T3-E1 cells, resulting in the stimulation of VEGF synthesis $(18,19)$. In the present study, we demonstrated that minodronate suppresses the phosphorylation of p44/p42 MAP kinase and SAPK/JNK induced by bFGF. These results suggest that minodronate exerted its inhibitory effect via the suppression of p44/p42 MAP kinase and SAPK/JNK in osteoblast-like MC3T3-E1 cells. In addition, we showed that minodronate alone induced the phosphorylation of p38 MAP kinase in MC3T3-E1 cells. It is well recognized that MAP kinases are activated by the phosphorylation of threonine and tyrosine residues by dual specificity MAP kinase $(25,26)$. Thus, it is probable that minodronate activates p38 MAP kinase in MC3T3-E1 cells, although the physiological relevance of this is not known. Taking our findings into account, it seems unlikely that the inhibitory effect on bFGF-stimulated VEGF synthesis is toxic in MC3T3-E1 cells.

VEGF is known to be a potent and specific mitogen of vascular endothelial cells (15). The expansion of the microvasculature is considered to be an essential process for the adequate turnover of bone cells in the process of bone remodeling (3). Therefore, the synthesis and secretion of VEGF by osteoblasts serves as a crucial intercellular mediator between osteoblasts and vascular endothelial cells in an autocrine/paracrine fashion. It has been shown that VEGF is involved in trabecular bone formation and the expansion of the hypertrophic chondrocyte zone in mouse epiphyseal growth plates (16). In addition, Flk-1, a VEGF receptor, is reportedly expressed in osteoblasts (27) and involved in bone formation synergistically with BMP-4 (28). In a previous study (20), we reported that incadronate amplifies $\mathrm{PGF}_{2 \alpha}$-induced VEGF synthesis in osteoblast-like MC3T3-E1 cells, while alendronate or ethidronate do not have a similar effect. These findings suggest that bisphosphonates have different molecular mechanisms of action on osteoblasts, most likely due to structural differences. It is generally known that there are considerable structural differences among bisphosphonates at the R2 side chain (4). Minodronate possesses (4-chlorophenyl) thiol-methylene structure, while incadronate possesses cycloheptylaminomethylene and 1-hydroxyethylidene structures
(4). These structural differences in the R2 side chain may result in the different effects had on the VEGF synthesis. In addition, the different effects of these bisphosphonates on VEGF synthesis may be related to the relative potency of these agents on the anti-bone resorptive activities. In metabolic bone diseases, bone remodeling rates differ on a case-tocase basis. To elucidate the unique agent-specific effect(s) of bisphosphonates and to ensure adequate therapeutics by these drugs, it may be possible to select bisphosphonates according to their specific effect on bone forming cells. Our present findings provide insight into the differences between the pharmacological effects of various bisphosphonates. These are possibly due to structural differences at the $\mathrm{R} 2$ side chain. Further investigation is necessary to clarify the exact mechanism of bisphosphonates in bone cells.

In conclusion, our present results strongly suggest that minodronate inhibits VEGF synthesis induced by bFGF in osteoblast-like MC3T3-E1 cells, and that the effect of minodronate is exerted through the suppression of $\mathrm{p} 44 / \mathrm{p} 42$ MAP kinase and SAPK/JNK.

\section{Acknowledgements}

This work was supported in part by a Grant-in-Aid for Scientific Research $(16590873,16591482)$ from the Ministry of Education, Science, Sports and Culture of Japan, and by Research Grants for Longevity Sciences (17A-3), Health and Labour Sciences Research Grants for Research on Longevity Sciences, and Research on Proteomics from the Ministry of Health, Labour and Welfare of Japan.

\section{References}

1. Nijweide PJ, Burger EH and Feyen JHM: Cells of bone: proliferation, differentiation and hormonal regulation. Physiol Rev 66: 855-886, 1986.

2. Suda T, Takahashi N, Udagawa N, Jimi E, Gillespie MT and Martin TJ: Modulation of osteoclast differentiation and function by the new members of the tumor necrosis factor receptor and ligand families. Endocrine Rev 20: 345-357, 1999.

3. Erlebacher A, Filvaroff EH, Girelman SE and Derynck R: Toward a molecular understanding of skeletal development. Cell 80: 371-378, 1995.

4. Fleisch H, Reszka A, Rodan GA and Rogers M: Bisphosphonates. In: Principles of Bone Biology. Bilezikian JP, Raisz LG and Rodan GA (eds). 2nd edition. Academic Press, San Diego, CA, pp1361-1385, 2002.

5. Sahni M, Guenther HL, Fleisch H, Collin P and Martin TJ: Bisphosphonates act on rat bone resorption through the mediation of osteoblasts. J Clin Invest 91: 2004-2011, 1993.

6. Nishikawa M, Akatsu T, Katayama Y, et al: Bisphosphonates act on osteoblastic cells and inhibit osteoclast formation in mouse marrow cultures. Bone 18: 9-14, 1995.

7. Vitte C, Fleisch H and Guenther HL: Bisphosphonates induce osteoblasts to secrete an inhibitor of osteoclast-mediated resorption. Endocrinology 137: 2324-2333, 1996

8. Tokuda H, Kozawa O, Harada A and Uematsu T: Tiludronate inhibits interleukin-6 synthesis in osteoblasts: Inhibition of phospholipase D activation in MC3T3-E1 cells. J Cell Biochem 69: 252-259, 1998.

9. Plotkin LI, Weinstein RS, Parfitt AM, Roberson PK, Manolagas SC and Bellido T: Prevention of osteocyte and osteoblast apoptosis by bisphosphonates and calcitonin. J Clin Invest 104: 1363-1374, 1999.

10. Reinholz GG, Getz B, Pederson L, Sanders ES, Subramaniam M, Ingle $\mathrm{JN}$ and Spelsberg TC: Bisphosphonates directly regulate cell proliferation, differentiation and gene expression in human osteoblasts. Cancer Res 60: 6001-6007, 2000. 
11. Viereck V, Emos G, Lauck V, Frosch KH, Blaschke S, Grundker C and Hofbauer LC: Bisphosphonates pamidronate and zoledronic acid stimulate osteoprotegerin production by primary human osteoblasts. Biochem Biophys Res Commun 291: 680-686, 2002.

12. Mackie PS, Fisher JL, Zhou H and Choong PF: Bisphosphonates regulate cell growth and gene expression in the UMR 106-01 clonal rat osteosarcoma cell line. Br J Cancer 84: 951-958, 2001

13. Pan B, To LB, Farrugia AN, et al: The nitrogen-containing bisphosphonate, zoledronic acid, increases mineralisation of human bone-derived cells in vitro. Bone 34: 112-123, 2004

14. Pan B, Farrugia AN, To LB, Findlay DM, Green J, Lynch K and Zannettino ACW: The nitrogen-containing bishphosphonate, zoledronic acid, influences RANKL expression in human osteoblast-like cells by activating TNF- $\alpha$ converting enzyme (TACE). J Bone Miner Res 19: 147-154, 2004.

15. Ferrara $\mathrm{N}$ and Davis-Smyth T: The biology of vascular endothelial growth factor. Endocrine Rev 18: 4-25, 1997.

16. Gerber HP, Vu TH, Ryan AM, Kowalski J, Werb Z and Ferrara N: VEGF couples hypertrophic cartilage remodeling, ossification and angiogenesis during endochondral bone formation. Nat Med 5: 623-628, 1999 .

17. Harada $\mathrm{S}$ and Thomas KA: Vascular endothelial growth factors. In: Principles of Bone Biology. Bilezikian JP, Ratsz LG and Rodan GA (eds). 2nd edition. Academic Press, San Diego, CA, pp883-902, 2002

18. Tokuda $\mathrm{H}$, Kozawa $\mathrm{O}$ and Uematsu $\mathrm{T}$ : Basic fibroblast growth factor stimulates vascular endothelial growth factor release in osteoblasts: divergent regulation by p42/p44 mitogen-activated protein kinase and p38 mitogen-activated protein kinase. J Bone Miner Res 15: 2371-2379, 2000.

19. Tokuda H, Hirade K, Wang X, Oiso Y and Kozawa O: Involvement of SAPK/JNK in basic fibroblast growth factor-induced vascular endothelial growth factor release in osteoblasts. J Endocrinol 177: 101-107, 2003.
20. Tokuda H, Harada A, Hirade K, et al: Incadronate amplifies prostaglandin $\mathrm{F}_{2 \alpha}$-induced vascular endothelial growth factor synthesis in osteoblasts: enhancement of MAPK activity. J Biol Chem 278: 18930-18937, 2003.

21. Sudo M, Kodama H, Amagai Y, Yamamoto S and Kasai S: In vitro differentiation and calcification in a new clonal osteogenic cell line derived from newborn mouse calvaria. J Cell Biol 96: 191-198, 1983.

22. Kozawa O, Suzuki A, Tokuda $\mathrm{H}$ and Uematsu T: Prostaglandin $\mathrm{F}_{2 \alpha}$ stimulates interleukin-6 synthesis via activation of PKC in osteoblast-like cells. Am J Physiol 272: 208-211, 1997.

23. Laemmli UK: Cleavage of structural proteins during the assembly of the head of bacteriophage T4. Nature 227: 680-685, 1970.

24. Kato K, Ito K, Hasegawa K, Inaguma Y, Kozawa O and Asano T: Modulation of the stress-induced synthesis of hsp27 and $\alpha \mathrm{B}$-crystalin by cyclic AMP in C6 rat glioma cells. J Neurochem 66: 946-950, 1996.

25. Widmann C, Gibson S, Jarpe MB and Johnson GL: Mitogenactivated protein kinase: conservation of a three-kinase module from yeast to human. Physiol Rev 79: 143-180, 1999.

26. Raingeaud J, Gupta S, Rogers JS, Dickens M, Han J, Ulevitch RJ and David RJ: Pro-inflammatory cytokines and enviromental stress cause p38 MAP kinase activation by dual phosphorylation on tyrosine and threonine. J Biol Chem 270: 7420-7426, 1995.

27. Karsenty G and Wagner EF: Reaching a genetic and molecular understanding of skeletal development. Dev Cell 2: 389-406, 2002.

28. Peng H, Wright V, Usas A, Gearhart B, Shen HC, Cummins J and Huard J: Synergistic enhancement of bone formation and healing by stem cell-expressed VEGF and bone morphogenic protein-4. J Clin Invest 110: 751-759, 2002. 